\title{
'n Ondersoek na die verwantskap tussen die intestinale mikrobioom en 'n kompulsiewe gedragsfenotipe in die hertmuismodel (deer mouse model) van obsessiewe-kompulsiewe siekte
}

\section{Outeurs: \\ Isma Scheepers, \\ BH Harvey, ${ }^{\text {ac }}$ \\ SMJ Hemmings, \\ S Malan-Müller, \\ D Wolmarans ${ }^{\mathrm{a}}$ \\ Affiliasies: \\ asentrum vir \\ Uitnemendheid vir Farma- \\ seutiese Wetenskappe, \\ Noordwes-Universiteit \\ Privaatsak X6001, \\ Potchefstroom, 2520 \\ bepartement Psigiatrie, \\ Universiteit Stellenbosch \\ Privaatsak X1, Matieland, \\ 7602 \\ cMNR-Eenheid vir \\ Risiko en Weerstand in \\ Geestesversteurings, \\ Potchefstroom}

Korresponderende outeur:

S Malan-Müller

E-pos: smalan@sun.ac.za

Hoe om hierdie artikel aan te haal:

Isma Scheepers, BH Harvey,

SMJ Hemmings, S Malan-

Müller, D Wolmarans,

' $n$ Ondersoek na die

verwantskap tussen die

intestinale mikrobioom

en 'n kompulsiewe

gedragsfenotipe in die

hertmuismodel (deer mouse

model) van obsessiewe-

kompulsiewe siekte,

Suid-Afrikaanse Tydskrif

vir Natuurwetenskap en

Tegnologie 38(1) (2019).

https://doi.org/10.36303/

SATNT.2019.38.1.774

\section{Kopiereg:}

(c) 2019. Authors.

Licensee: Die Suid-

Afrikaanse Akademie vir

Wetenskap en Kuns.

Hierdie werk is onder

die Creative Commons

Attribution License

gelisensieer.
An investigation into the relationship between the intestinal microbiota and a compulsive phenotype in the deer mouse model of obsessive-compulsive disorder: Recent research highlighted the possible role of gut-microbiota in the etiopathology of psychiatric illness. However, studies investigating the exact nature of and mechanisms underlying such possible relationships are lacking. This study aims to provide such insight in a validated animal model of obsessive-compulsive disorder (OCD).

Obsessiewe-kompulsiewe siekte (OKS) word gekenmerk deur aanhoudende, indringende en ongewenste gedagtes (obsessies) en herhalende gedragspatrone (kompulsies). Onlangse navorsing dui op die betrokkenheid van die intestinale mikrobioom in die patogenese van psigiatriese siektes. Studies wat poog om die presiese rol hiervan, veral in OKS, te verduidelik, is egter skaars. Derhalwe het hierdie ondersoek ten doel om te bepaal of kompulsiefagtige gedrag in ' $n$ bestaande dieremodel van OKS, naamlik groot nesbougedrag (GNB) in hertmuise (Peromyscus maniculatus bairdii), moontlik verband hou met unieke intestinale mikrobioomeienskappe. Daar word ook ondersoek ingestel of hierdie eienskappe in so 'n mate deur'n geneesmiddel, wat vir die behandeling van kliniese OKS gebruik word, manipuleerbaar is dat dit dié van normale kontrolediere sou kon voorstel. Die doel hiermee is om moontlike organismes wat by die patogenese en behandelingsuitkomste van OKS betrokke mag wees, te identifseer.

Die doelwitte van hierdie studie is dus as volg: 1) om te bepaal of daar verskille tussen die mikrobiota-samestelling van kontrole- en kompulsiefagtige hertmuise bestaan; en 2) om die effek van kroniese essitalopram-behandeling $(50 \mathrm{mg} / \mathrm{kg} /$ dag toegedien in drinkwater vir 28 dae) op die mikrobiota te bepaal. Twee groepe muise is gebruik, wat elk in twee kleiner groepe verdeel is ( $n=6$ per gedragsgroep vir studiedoelwit 1 en $n=5$ per gedragsgroep vir studiedoelwit 2). Om die hertmuise in normale nesbougedrag (NNB)- en GNB-groepe in te deel en in ag genome dat slegs 30\% van die normale hertmuispopulasie GNB-gedrag toon, is nesbougedrag aanvanklik in 40 hertmuise vir sewe opeenvolgende dae in die spesifieke patogeenvrye (SPV) area van die Vivarium van die Noordwes-Universiteit waargeneem. Hierna is fekale monsters van die geïdentifiseerde hertmuise versamel en bakteriële DNA onttrek en ontleed met behulp van nuwe-generasie 16S-rRNA-geenopklaring, spesifiek gerig op die uiters wisselende V3V4 grepe. Hierdie stap is herhaal na die kroniese behandelingstydperk in studiedoelwit 2. PhyloSeq-sagteware is gebruik vir die bepaling van beide $\alpha$ (binne 'n bepaalde individu) en $\beta$ (tussen verskillende hertmuise) en om die taksa te identifiseer wat in die meeste organismes voorkom. R-Studio-sagteware is vir statistiese ontledings gebruik.

Hoewel die data-ontleding teen einde 2018 in 'n vroeë stadium van voltooiing was, is die resultate vooruitspruitend uit die bovermelde ontledings by die jaarlikse Studentesimposium in die Natuurwetenskappe van die Suid-Afrikaanse Akademie vir Wetenskap en Kuns aangebied en bespreek. Sover die outeurs se kennis strek, is hierdie die eerste studie waarin 'n dieremodel van OKS gebruik word om 'n moontlike verband tussen die intestinale mikrobioom en die simptomologie van OKS te bepaal.

Nota: 'n Seleksie van referaatopsommings: Studentesimposium in die Natuurwetenskappe, 25-26 Oktober 2018, SA Akademiegebou, Pretoria, Suid-Afrika. Gasredakteurs: Prof Rudi Pretorius (Departement Geografie, Universiteit van Suid-Afrika); Prof Chris Swanepoel (Departement Besluitkunde, Universiteit van Suid-Afrika); Me Andrea Lombard (Departement Geografie, Universiteit van Suid-Afrika) 